\title{
Poultry Offal Meal as a Substitute to Dietary Soybean Meal for Japanese Quails (Coturnix coturnix japonica): Assessing the maximum inclusion level and the Effect of Supplemental Enzymes
}

\author{
R.K. Mutucumarana, K. Samarasinghe ${ }^{1}$, G.W.H.A.A. Ranjith ${ }^{2}$ \\ A.W. Wijeratne ${ }^{3}$ and D.D. Wickramanayake ${ }^{4}$ \\ Department of Livestock Production \\ Faculty of Agricultural Sciences \\ Sabaragamuwa University of Sri Lanka \\ Sri Lanka
}

\begin{abstract}
The proximate composition, pepsin digestibility, gross energy and macro mineral contents of 12 composite samples of poultry offal meal produced in Sri Lanka were analyzed. The average dry matter, ash, crude protein, crude fiber, ether extract, in vitro pepsin digestibility and gross energy of poultry offal meal were 92.3, 6.9, 48.9, 2.1, 32.4, $83.8 \%$ and $23.6 \mathrm{MJ} \mathrm{kg}^{-1}$, respectively. The average $\mathrm{Ca}, \mathrm{P}$ and $\mathrm{Mg}$ contents were 2.36, 1.10 and $0.09 \%$, respectively. The replacement value of poultry offal meal for soybean meal and the effect of supplementation of poultry offal meal by dietary enzymes (Solid state fermentation and Lipase) on the performance of Japanese quails fed isocaloric and isonitrogenous diets were studied in two experiments. Unsexed Japanese quails (13 days old; $N=200$ ) were randomly assigned to twenty groups. In experiment 1 , poultry offal meal was incorporated at 0, 2.5, 5, 7.5 and 10\% of the diets and fed until 15 weeks of age. In experiment 2, the performance of Japanese quails fed with diets containing 0, 5 and 10\% poultry offal meal was investigated. Enzyme effect was tested with diets containing 5 and $10 \%$ poultry offal meal. Cost benefit analyses were carried out to find out the most cost effective treatment. The quails fed with diets containing 5 and $10 \%$ poultry offal meal produced higher number of eggs $(P<0.05)$ than those fed with 2.5 and $7.5 \%$ poultry offal meal containing diets. Supplementation of enzymes improved egg production by $21.9 \%$ only when $5 \%$ poultry offal meal was incorporated into the diet. The diet having $10 \%$ poultry offal meal was identified as the most cost effective treatment in terms of feed cost per kg live weight gain whereas 5\% poultry offal meal diet was the best in terms of feed cost per $\mathrm{kg}$ eggs. Incorporation of poultry offal meal at 10\% level cut down the feed cost per kg live weight gain by $4.6 \%$ as compared to the control diet. Cost benefit analysis showed that diet with $10 \%$ was the most cost effective. Enzyme supplementation cut down the mean feed cost per $\mathrm{kg}$ eggs by $26.9 \%$ only in the diets with $5 \%$ poultry offal meal level.
\end{abstract}

Department of Animal Science, Faculty of Agriculture, University of Peradeniya, Peradeniya, Sri Lanka

2 Department of Animal Production and Health, VS Office- Haldummulla, Sri Lanka

3 Department of Agribusiness Management, Faculty of Agricultural Sciences, Sabaragamuwa University of Sri Lanka, Belihuloya, Sri Lanka

4 Department of Livestock Production, Faculty of Agricultural Sciences, Sabaragamuwa University of Sri Lanka, Belihuloya, Sri Lanka 


\section{INTRODUCTION}

Feed cost is the major determinant of profitability in poultry production accounting for 70$80 \%$ of total cost of production (Daghir, 1975) and Sri Lanka is no exception. Hence, research on finding alternative feed ingredients available in Sri Lanka, where protein supplements is a major challenge, is particularly important. The feeding value of poultry byproduct meals for poultry as a novel protein supplement was first established at the beginning of the 1950's (Samli et al., 2006).

However, large quantities of poultry offal, which can be used as a valuable source of protein, mineral and fat for feeding livestock species, are wasted in Sri Lanka leading to environmental hazards. Moreover, the use of poultry offal meal (POM) in poultry feeds will conserve environment, reduce cost of production and leave savings on foreign exchange by reducing the volume of importation of protein supplements (Escalona and Pesti, 1987). Poultry offal meal, which is produced by rendering poultry processing wastes including head, feet, viscera, fat, blood and feathers together with hatchery wastes, is the most common by-product meal derived from poultry processing in Sri Lanka (Samarasinghe, 2007). The evaluation of alternative feed stuffs such as POM generally focus on replacing conventional, high cost protein supplements due to its low cost and high crude protein content.

Currently, imported soybean meal (SBM) is incorporated into poultry rations as the main source of protein in Sri Lanka. Dudley (2001) stated that the digestibility of dry matter and gross energy in SBM is nearly 50\% when fed to poultry. Furthermore, SBM contains a heat stable antinutritive factor called phytic acid (Banerjee, 1998) and contains trypsin inhibitors, hemagglutinins and lectins as antinutrients, which may contribute to growth retardation in monogastric animals (NRC, 1994). In contrast to SBM, POM has no such drawbacks as a feed stuff since it has an animal origin.

Japanese quails (Coturnix coturnix japonica) have become a growing part of the commercial poultry industry providing both meat and eggs for consumers at an affordable price (Gopalkrishnan, 2003). Unavailability of specific quail rations in Sri Lanka to satisfy the nutritional requirement of Japanese quails detracts the interest of local farmers in rearing quails. Therefore, testing of existing cheap, non-conventional feed ingredients such as POM in diet formulation for Japanese quails is of utmost importance.

The commercially available feed enzymes improve animal performance and permit the utilization of higher levels of agro-industrial by-products for monogastric animals (Attia et al., 2008). The level of inclusion of POM in rations for chicken has been low due to its poor nutritional quality which can be improved by supplemental enzymes (Samarasinghe et al., 2002). However, reports on feeding POM with or without enzymes to Japanese quails are scanty.

The present study was therefore conducted to establish the maximum inclusion level of POM in rations for Japanese quails and to determine the effect of enzyme supplementation on the performance of Japanese quails fed diets containing POM as a partial replacement of soybean meal. 


\section{MATERIALS AND METHODS}

Dry rendered POM derived from an industrial poultry slaughterhouse in Gampola, Sri Lanka was collected during random sampling period of three months. Three samples collected in eight day intervals were mixed together and composite samples (12) were prepared and analyzed in duplicates to obtain average values.

The dry matter (DM), ash, crude protein (CP), crude fiber (CF), ether extract (EE), Ca, P, Mg and in vitro pepsin digestibility of the POM samples were determined according to AOAC (2002) procedures, and the gross energy was determined by an adiabatic oxygen bomb calorimeter (Rajdhani Scientific Inst. Co. New Delhi) using the method described by Harris, 1966.

\section{Experimental design}

Two feeding trials were conducted, each with 200 unsexed Japanese quail chicks at 12 days of age. They were procured from a commercial quail breeder farm in Balangoda and transferred to battery cages installed in a poultry house at the University Farm, Sabaragamuwa University of Sri Lanka. On the following day, they were divided into 20 groups of ten in such a way that the average group weights were similar and then housed in 20 battery cages of 40x40x25 cm ( $\mathrm{LxW} \times \mathrm{H})$ in size. Feeds and water were given ad libitum during the experimental period.

\section{Experimental diets}

For the first experiment, five isoenergetic and isoproteic rations containing pre-analyzed POM at $0,2.5,5,7.5$ and $10 \%$ inclusion levels were produced for "growers" and "layers" separately (Table 1). Birds were fed on grower diets up to 5 weeks of age and thereafter on layer feeds until they were 15 weeks old.

For the second experiment, three isoenergetic and isoproteic grower and layer diets containing 0,5 and $10 \%$ levels of pre-analyzed POM without enzymes and two POM diets (5 and $10 \%$ POM) supplemented with a mixture of solid state fermentation enzymes (SSF) and Lipase at 200 ppm were prepared and fed until 16 weeks of age (Table 2). According to the producers, SSF possesses the activities of seven enzymes (phytase, protease, pentosanase, glucanase, cellulase, amylase and pectinase) which are capable of breaking down protein, cellulose, pentosans, phytate and starch.

All the diets were formulated to satisfy the nutrient requirements of growing and laying quails according to Leeson and summers (2005). Metabolizable energy (ME) content of POM for ration formulation was calculated according to the formula described by Janssen (1989). The feed without POM (0\%) was considered as the control feed while the others served as test feeds. In both trials, the experimental diets were randomly assigned to 20 groups of birds with four replicates for each feed.

Samples of experimental feeds were collected every $4^{\text {th }}$ day during feeding, pooled separately and composite samples made were analyzed in duplicate for proximate composition according to standard procedures of the Association of Official Analytical Chemists (AOAC, 2002) and for gross energy by bomb calorimetry (Harris, 1966). 
Table 1. Composition of the diets fed to Japanese quail growers and layers in experiment 1

\begin{tabular}{|c|c|c|c|c|c|c|c|c|c|c|}
\hline \multirow[t]{3}{*}{ Ingredients (\%) } & \multicolumn{10}{|c|}{ Experiment 1 } \\
\hline & \multicolumn{5}{|c|}{ Grower (3-5 weeks) } & \multicolumn{5}{|c|}{ Layers (5-15 weeks) } \\
\hline & T1 & T2 & T3 & T4 & T5 & T1 & $\mathbf{T 2}$ & T3 & T4 & T5 \\
\hline Rice polish & 20 & 20 & 20 & 20 & 20 & 15.9 & 15.9 & 16 & 16 & 16 \\
\hline Maize & 45 & 45 & 45 & 45 & 45 & 43 & 43 & 44.7 & 45.9 & 47 \\
\hline Coconut oil & - & - & - & - & - & 2 & 2 & 1.5 & 1 & 0.6 \\
\hline Soybean meal & 20 & 17 & 13.7 & 10.4 & 7.0 & 27.2 & 24 & 21 & 18 & 14.9 \\
\hline POM & 0.0 & 2.5 & 5.0 & 7.5 & 10 & 0.0 & 2.5 & 5.0 & 7.5 & 10 \\
\hline Coconut poonac & 6.20 & 6.70 & 7.68 & 8.60 & 9.65 & - & 0.7 & - & - & - \\
\hline Shell grit powder & 7.00 & 7.00 & 6.80 & 6.67 & 6.50 & 9.7 & 9.7 & 9.6 & 9.4 & 9.3 \\
\hline Dicalcium phosphate & 0.75 & 0.75 & 0.75 & 0.75 & 0.75 & 1.35 & 1.35 & 1.35 & 1.35 & 1.35 \\
\hline Lysine $\mathrm{HCl}$ & 0.15 & 0.15 & 0.17 & 0.18 & 0.20 & - & - & - & - & 0.02 \\
\hline DL Methionine & 0.30 & 0.30 & 0.30 & 0.30 & 0.30 & 0.25 & 0.25 & 0.25 & 0.25 & 0.23 \\
\hline Salt & 0.25 & 0.25 & 0.25 & 0.25 & 0.25 & 0.25 & 0.25 & 0.25 & 0.25 & 0.25 \\
\hline Coccidiostats & 0.05 & 0.05 & 0.05 & 0.05 & 0.05 & 0.05 & 0.05 & 0.05 & 0.05 & 0.05 \\
\hline Zn Bacitracin & 0.05 & 0.05 & 0.05 & 0.05 & 0.05 & 0.05 & 0.05 & 0.05 & 0.05 & 0.05 \\
\hline Vitamin mineral premix* & 0.25 & 0.25 & 0.25 & 0.25 & 0.25 & 0.25 & 0.25 & 0.25 & 0.25 & 0.25 \\
\hline Calculated composition: & & & & & & & & & & \\
\hline $\mathrm{ME}(\mathrm{MJ} / \mathrm{kg})$ & 12.1 & 12.2 & 12.2 & 12.2 & 12.3 & 12.4 & 12.4 & 12.4 & 12.4 & 12.4 \\
\hline $\mathrm{CP}(\mathrm{g} / \mathrm{kg})$ & 170.3 & 170.6 & 170.8 & 170.8 & 170.8 & 180.7 & 180.5 & 180.2 & 180.7 & 180.7 \\
\hline Lysine $(\mathrm{g} / \mathrm{kg})$ & 9.54 & 9.46 & 9.48 & 9.42 & 9.42 & 9.89 & 9.77 & 9.69 & 9.63 & 9.69 \\
\hline Methionine $(\mathrm{g} / \mathrm{kg})$ & 7.68 & 7.56 & 7.42 & 7.27 & 7.12 & 7.73 & 7.59 & 7.45 & 7.33 & 7.00 \\
\hline Met +Cys $(\mathrm{g} / \mathrm{kg})^{* *}$ & 8.54 & 8.66 & 8.76 & 8.86 & 8.95 & 8.54 & 8.65 & 8.79 & 8.94 & 8.87 \\
\hline
\end{tabular}

$\mathrm{T} 1=$ Control. $\mathrm{T} 2=2.5 \%$ POM diet. T3= 5.0\% POM diet. T4= 7.5\% POM diet. T5=10\% POM diet

*Layer premix B; Each $2.5 \mathrm{~kg}$ Layer premix B contained: vitamin A 8 miu, vitamin $\mathrm{D}_{3} 2$ miu, vitamin E $4000 \mathrm{mg}$, vitamin $\mathrm{K} 1000 \mathrm{mg}$, vitamin $\mathrm{B}_{1} 2000 \mathrm{mg}$, vitamin $\mathrm{B}_{2} 3600$ $\mathrm{mg}$, vitamin $\mathrm{B}_{6} 1000 \mathrm{mg}$, vitamin $\mathrm{B}_{12} 10 \mathrm{mg}$, calcium pantothenate $6000 \mathrm{mg}$, choline chloride $150000 \mathrm{mg}$, folic acid $500 \mathrm{mg}$, niacinamide $20000 \mathrm{mg}$, D. L methionine 250000 mg. Trace mineral; Each $2.5 \mathrm{~kg}$ Layer premix B contained: Iron $20000 \mathrm{mg}$, Manganese $40000 \mathrm{mg}$, Copper $5000 \mathrm{mg}$, Zinc $50000 \mathrm{mg}$, Iodine $500 \mathrm{mg}$ and Cobolt $100 \mathrm{mg}$.

$* *$ Met + Cys: Methionine + Cysteine 
Table 2. Composition of the diets fed to Japanese quail growers and layers in experiment 2

\begin{tabular}{|c|c|c|c|c|c|c|c|c|c|c|}
\hline \multirow{3}{*}{ Ingredients (\%) } & \multicolumn{9}{|c|}{ Experiment 2} & \\
\hline & \multicolumn{5}{|c|}{ Grower (3-5 weeks) } & \multicolumn{5}{|c|}{ Layers (5-15 weeks) } \\
\hline & T1 & T3 & T5 & $\mathbf{T 3}+\mathbf{E}$ & $\mathbf{T 5}+\mathbf{E}$ & T1 & T3 & T5 & $\mathbf{T 3}+\mathbf{E}$ & $\mathbf{T 5}+\mathbf{E}$ \\
\hline Rice polish & 20 & 20 & 20 & 20 & 20 & 15.9 & 16 & & 16 & \\
\hline Maize & 45 & 43.5 & 42 & 43.5 & 42 & 43 & 43 & 44 & 43 & 44 \\
\hline Coconut oil & - & - & - & - & - & 2 & 1.5 & 0.8 & 1.5 & 0.8 \\
\hline Soybean meal & 20 & 13.3 & 7.0 & 13.3 & 7.0 & 27.2 & 21 & 15 & 21 & 15 \\
\hline POM & 0.0 & 5.0 & 10 & 5.0 & 10 & 0.0 & 5.0 & 10 & 5.0 & 10 \\
\hline Coconut poonac & 6.20 & 10.2 & 13.1 & 10.2 & 13.1 & - & 2 & 3.4 & 2 & 3.4 \\
\hline Shell grit powder & 7.00 & 6.5 & 6.5 & 6.5 & 6.5 & 9.7 & 9.55 & 9.1 & 9.55 & 9.1 \\
\hline Dicalcium phosphate & 0.75 & 0.43 & 0.3 & 0.43 & 0.3 & 1.35 & 1.1 & 0.9 & 1.1 & 0.9 \\
\hline Lysine $\mathrm{HCl}$ & 0.15 & 0.17 & 0.20 & 0.17 & 0.20 & - & - & - & - & - \\
\hline DL Methionine & 0.30 & 0.30 & 0.30 & 0.30 & 0.30 & 0.25 & 0.25 & 0.20 & 0.25 & 0.20 \\
\hline Salt & 0.25 & 0.25 & 0.25 & 0.25 & 0.25 & 0.25 & 0.25 & 0.25 & 0.25 & 0.25 \\
\hline Coccidiostats & 0.05 & 0.05 & 0.05 & 0.05 & 0.05 & 0.05 & 0.05 & 0.05 & 0.05 & 0.05 \\
\hline Zn Bacitracin & 0.05 & 0.05 & 0.05 & 0.05 & 0.05 & 0.05 & 0.05 & 0.05 & 0.05 & 0.05 \\
\hline Vitamin mineral premix* & 0.25 & 0.25 & 0.25 & 0.25 & 0.25 & 0.25 & 0.25 & 0.25 & 0.25 & 0.25 \\
\hline $\mathrm{SSF}(\mathrm{ppm}) * *$ & - & - & - & 200 & 200 & - & - & - & 200 & 200 \\
\hline Lipase (ppm) & - & - & - & 200 & 200 & - & - & - & 200 & 200 \\
\hline \multicolumn{11}{|l|}{ Calculated composition: } \\
\hline $\mathrm{ME}(\mathrm{MJ} / \mathrm{kg})$ & 12.1 & 12.2 & 12.2 & 12.2 & 12.2 & 12.4 & 12.3 & 12.4 & 12.3 & 12.4 \\
\hline $\mathrm{CP}(\mathrm{g} / \mathrm{kg})$ & 170.3 & 170.6 & 170.6 & 170.6 & 170.6 & 180.7 & 180.5 & 180.5 & 180.5 & 180.5 \\
\hline Lysine (g/kg) & 9.54 & 9.44 & 9.49 & 9.44 & 9.49 & 9.89 & 9.74 & 9.64 & 9.74 & 9.64 \\
\hline Methionine (g/kg) & 7.68 & 7.43 & 7.20 & 7.43 & 7.20 & 7.73 & 7.50 & 6.80 & 7.50 & 6.80 \\
\hline Met. + Cyst. (g/kg) & 8.54 & 8.75 & 8.97 & 8.75 & 8.97 & 8.54 & 8.81 & 8.62 & 8.81 & 8.62 \\
\hline
\end{tabular}

$\mathrm{T} 1=$ Control. $\mathrm{T} 3=5.0 \%$ POM diet. T5= 10\% POM diet T3+E= Enzyme supplemented 5\% POM diet and T5 + E= Enzyme supplemented 10\% POM diet

*Layer premix B; Each $2.5 \mathrm{~kg}$ Layer premix B contained: vitamin A 8 miu, vitamin $\mathrm{D}_{3} 2$ miu, vitamin E $4000 \mathrm{mg}$, vitamin $\mathrm{K} 1000 \mathrm{mg}$, vitamin $\mathrm{B}_{1} 2000 \mathrm{mg}$, vitamin $\mathrm{B}_{2} 3600$ $\mathrm{mg}$, vitamin $\mathrm{B}_{6} 1000 \mathrm{mg}$, vitamin $\mathrm{B}_{12} 10 \mathrm{mg}$, calcium pantothenate $6000 \mathrm{mg}$, choline chloride $150000 \mathrm{mg}$, folic acid $500 \mathrm{mg}$, niacinamide $20000 \mathrm{mg}$, D. L methionine 250000 mg. Trace mineral; Each $2.5 \mathrm{~kg}$ Layer premix B contained: Iron $20000 \mathrm{mg}$, Manganese $40000 \mathrm{mg}$, Copper $5000 \mathrm{mg}$, Zinc $50000 \mathrm{mg}$, Iodine $500 \mathrm{mg}$ and Cobolt $100 \mathrm{mg}$.

** SSF each $1.0 \mathrm{~g}$ contained: Alpha-amylase min. $30 \mathrm{FAU}$, beta-glucanase min. $200 \mathrm{BGU}$, cellulase min.10 CMC, pectinase min. 4000 AJDU, phytase 300 SPU, fungal protease min. 700 HUT, xylanase min. $100 \mathrm{XU}$. 


\section{Parameters studied}

The birds were first weighed at 13 days of age and thereafter weekly until the commencement of laying. Final group body weights were measured at the end of the feeding trial. Group feed intake was recorded weekly.

The egg production was recorded daily for each group to calculate the average laying percentage. Feed conversion ratio (FCR) was calculated as the amount of feed (kg) consumed to produce a dozen eggs and the amount of feed $(\mathrm{kg})$ consumed to produce $\mathrm{kg} \mathrm{egg}$ mass. Any mortality during the experiment was recorded. Cost benefit analysis was done to determine the most cost effective treatment in each experiment. The feed cost per kg live weight gain and the feed cost per kg egg mass were calculated for each treatment in both experiments.

\section{Statistical analysis}

The average values obtained for proximate composition, mineral contents, gross energy and pepsin digestibility of POM were compared with the standard values (NRC, 1994) using one sided t-test by Minitab (Version 14.0) computer software. The two experiments were conducted in a completely randomized design and the data were analyzed using GLM procedure of SAS (Version 9.0) computer software. Comparison of means was done by least square followed by GLM procedure. The mortality data from both trials were analyzed by Chi-square test. The cost benefit data were analyzed by performing analysis of variance (ANOVA) using Minitab (Version 14.0) computer software.

\section{RESULTS AND DISCUSSION}

\section{Chemical composition of poultry offal meal and experimental diets}

The nutrient composition of POM used in the experiments and the corresponding NRC (1994) reference values are given in Table 3.

The average DM and $\mathrm{CF}$ of $\mathrm{POM}$ were not significantly different $(\mathrm{P}>0.05)$ from those reported by NRC (1994). The average ash percentage and CP content were significantly $(\mathrm{P}<0.05)$ lower than the values reported by NRC $(1994)$. The average ether extract content of POM samples $(32.4 \%)$ was higher $(\mathrm{P}<0.05)$ than that reported by NRC (1994). This is because the fat has not been removed from the final product during the rendering process of POM. Although the presence of high fat content can be beneficial in providing energy for animals, it reduces the nutritional value of POM due to its negative effect on digestibility and keeping quality. The average $\mathrm{Ca}, \mathrm{P}$ and $\mathrm{Mg}$ contents obtained were significantly lower than the reference values reported by NRC (1994). The average gross energy of POM samples was $23.6 \mathrm{MJ} / \mathrm{kg}$. This value is similar to the value reported by Najafabadi et al., (2007). The average pepsin digestibility was $83.8 \%$ and is in close agreement with the value $(80.9 \%)$ obtained by El-Sheikh et al., (1996). According to Najafabadi et al., (2007) the reason for variation in the nutritive values of POM may be due to the variation in source and types of raw materials, storage time of raw materials prior to rendering and processing conditions . 
Table 3. Nutrient composition of POM samples collected during the study period and the composition of POM used in each experiment

\begin{tabular}{|c|c|c|c|c|c|c|}
\hline \multirow[b]{2}{*}{ Sample No } & \multicolumn{6}{|c|}{ Poultry offal meal } \\
\hline & $\begin{array}{c}\text { Averag } \\
\text { e } \\
(n=12)\end{array}$ & $\mathrm{SD}^{1}$ & $\begin{array}{l}C^{2} \\
(\%)\end{array}$ & $\begin{array}{l}\text { NRC } \\
(1994)\end{array}$ & $\begin{array}{c}\text { Experiment } \\
1\end{array}$ & $\begin{array}{c}\text { Experiment } \\
2\end{array}$ \\
\hline Dry Matter (\%) & 92.3 & 1.12 & 1.22 & 93.0 & 90.8 & 85.27 \\
\hline $\operatorname{Ash}(\%)$ & 6.89 & 2.31 & 33.51 & $15.5 *$ & 7.95 & 6.56 \\
\hline Crude protein $(\%)$ & 48.91 & 2.54 & 5.19 & $60 *$ & 50.15 & 45.96 \\
\hline Crude Fiber (\%) & 2.05 & 0.97 & 47.29 & 1.5 & 1.4 & 1.53 \\
\hline Ether extract $(\%)$ & 32.39 & 2.62 & 8.09 & $13 *$ & 25.9 & 25.71 \\
\hline $\operatorname{NFE}(\%)$ & 2.06 & 1.35 & 65.62 & $3 *$ & 5.4 & 5.51 \\
\hline Calcium $(\%)$ & 2.36 & 0.38 & 16.3 & $3 *$ & 2.2 & 2.91 \\
\hline Magnesium (\%) & 0.09 & 0.02 & 24.31 & $0.22 *$ & 0.07 & - \\
\hline Phosphorous (\%) & 1.1 & 0.09 & 7.96 & $1.7 *$ & 1.2 & 0.83 \\
\hline Gross energy(MJ/kg) & 23.6 & 2.46 & 10.42 & - & 22.2 & 17.7 \\
\hline Pepsin digestibility (\%) & 83.8 & 3.29 & 3.92 & - & 83.15 & - \\
\hline $\begin{array}{l}\text { Metabolizable energy } \\
(\mathrm{MJ} / \mathrm{kg})\end{array}$ & - & - & - & - & 15.0 & 14.5 \\
\hline
\end{tabular}

However, POM seemed to be a good source of protein compared to SBM where the CP content is $44 \%$ (NRC. 1994). Furthermore, the average Ca and $\mathrm{P}$ contents obtained for POM were significantly $(\mathrm{P}<0.05)$ higher than the reference values reported for SBM $(0.29 \%$ and $0.65 \%$ respectively by NRC (1994). Similarly, the average EE content of POM revealed in the present study was significantly $(\mathrm{P}<0.05)$ higher than that reported by NRC (1994) for SBM $(0.8 \%)$. The average CF content of POM was significantly $(\mathrm{P}<0.05)$ lower than that reported for SBM $(7.0 \%)$ revealing a higher potential of dry matter digestibility of POM than that of SBM.

As shown in Table 4, the nutrient composition of experimental diets was similar and showed only small differences between treatments.

\section{Experiment 1}

\section{Weight gain}

Mean body weight gain was not significantly $(\mathrm{P}>0.05)$ different among birds fed with different diets (Table 5). Pesti (1987) also reported that there was no significant effect on growth rate due to inclusion of POM at 5\% level in male chicken. Fritts et al. (2002) indicated that feeding POM up to $10 \%$ fulfills the amino acid requirement of poultry. The present study proved the assertion that the amino acids in POM are sufficiently balanced to be considered in the formulation of quail rations and can be successfully used to replace dietary SBM up to $10 \%$ without having any negative effect on weight gain. However, Ertürk 
and Celik, (2004) reported that live weight gain of female quails was affected by the diets containing different inclusion levels of POM.

Table 4. Mean chemical composition and gross energy contents of the experimental diets fed to Japanese quails

Experiment 1

\begin{tabular}{|c|c|c|c|c|c|c|c|c|c|c|}
\hline \multirow[b]{2}{*}{ Component } & \multicolumn{5}{|c|}{ Grower } & \multicolumn{5}{|c|}{ Layer } \\
\hline & T1 & $\mathbf{T 2}$ & T3 & T4 & T5 & T1 & T2 & T3 & T4 & T5 \\
\hline$\overline{\mathrm{DM}(\%)}$ & 89.93 & 90.39 & 90.74 & 90.99 & 91.17 & 90.00 & 89.60 & 90.05 & 89.50 & 90.20 \\
\hline $\mathrm{CP}(\%)$ & 17.56 & 17.18 & 17.16 & 17.56 & 17.89 & 18.36 & 18.13 & 18.12 & 18.24 & 18.76 \\
\hline $\mathrm{CF}(\%)$ & 6.50 & 6.50 & 6.50 & 6.40 & 6.10 & 5.85 & 5.45 & 5.25 & 4.85 & 4.8 \\
\hline $\mathrm{EE}(\%)$ & 6.40 & 7.10 & 8.00 & 8.96 & 9.50 & 7.05 & 8.15 & 8.15 & 8.90 & 9.40 \\
\hline Ash (\%) & 17.56 & 17.18 & 17.16 & 17.56 & 17.89 & 17.5 & 17.05 & 16 & 15.8 & 16.7 \\
\hline NFE $(\%)$ & 48.19 & 47.81 & 46.95 & 46.27 & 45.95 & 41.24 & 40.83 & 42.53 & 41.71 & 40.55 \\
\hline $\mathrm{GE}(\mathrm{MJ} / \mathrm{kg})$ & 18.16 & 16.63 & 16.64 & 17.65 & 16.64 & 16.13 & 15.12 & 16.63 & 15.62 & 15.63 \\
\hline \multicolumn{11}{|c|}{ Experiment 2} \\
\hline & \multicolumn{5}{|c|}{ Grower } & \multicolumn{5}{|c|}{ Layer } \\
\hline Component & T1 & T3 & T5 & T3+E & T5+E & T1 & T3 & T5 & $\mathbf{T 3 + E ^ { \prime }}$ & T5+E \\
\hline$\overline{\mathrm{DM}(\%)}$ & 89.05 & 90.14 & 89.21 & 89.05 & 89.84 & 88.56 & 88.70 & 88.84 & 88.36 & 88.27 \\
\hline $\mathrm{CP}(\%)$ & 17.80 & 17.93 & 17.21 & 17.82 & 17.70 & 18.27 & 18.08 & 18.13 & 18.13 & 18.87 \\
\hline $\mathrm{CF}(\%)$ & 4.99 & 5.76 & 5.41 & 6.06 & 6.16 & 5.15 & 5.26 & 5.20 & 5.85 & 5.76 \\
\hline $\mathrm{EE}(\%)$ & 7.63 & 6.78 & 8.03 & 8.13 & 6.96 & 7.65 & 7.70 & 8.21 & 8.29 & 8.08 \\
\hline Ash (\%) & 11.88 & 11.25 & 11.69 & 11.38 & 11.64 & 16.45 & 16.36 & 16.41 & 16.45 & 15.02 \\
\hline NFE $(\%)$ & 46.75 & 48.42 & 46.87 & 45.66 & 47.38 & 41.04 & 41.30 & 40.89 & 39.64 & 40.54 \\
\hline GE (MJ/kg) & 15.50 & 15.51 & 16.05 & 16.05 & 16.57 & 15.53 & 15.55 & 15.61 & 15.04 & 15.06 \\
\hline
\end{tabular}

$\mathrm{DM}=$ Dry matter. $\mathrm{CP}=$ Crude protein. $\mathrm{CF}=\mathrm{Crude}$ fiber. $\mathrm{EE}=$ Ether extract. NFE= Nitrogen free extract. GE $=\mathrm{Gross}$ energy

$\mathrm{T} 1=$ Control. $\mathrm{T} 2=2.5 \% \mathrm{POM}$ diet. $\mathrm{T} 3=5.0 \% \mathrm{POM}$ diet. $\mathrm{T} 4=7.5 \% \mathrm{POM}$ diet. $\mathrm{T} 5=10 \% \mathrm{POM}$ diet $\mathrm{T} 3+\mathrm{E}=\mathrm{Enzyme}$ supplemented 5\% POM diet. T5+ E= Enzyme supplemented 10\% POM diet

As described by Escalona and Pesti (1987), chick growth was significantly depressed when POM was incorporated into the diet at $10 \%$ level. The results of the present experiment indicated that POM can be included up to $10 \%$ in diets of Japanese quails without an impairment of live weight gain. Differences between the results of the present experiment and those of the others might be due to higher quality of POM used in the present study or differences in heat processing of raw materials at rendering (Escalona and Pesti, 1987; Ertürk and Celik, 2004). Heat processing of protein sources may change L-amino acids to form Damino acids which may decrease their digestibility and bio-availability (Hassanabadi et al., 2008).

\section{Feed intake}

There was no significant influence of dietary treatments on the mean feed intake of birds (Table 5). In contrast to this observation, Ertürk and Celik (2004) found that the feed intake of quails fed with different levels of POM protein in diets were different from the group fed with control diet. High fat content of POM tends to increase the energy density of feed and consequently decrease the feed intake (Bolu and Adakeja, 2008). This might be the reason for having numerically low feed intake at $10 \%$ inclusion level compared to the control. 
Lower palatability of POM as compared to SBM might be the other reason for having lower feed intake by birds fed with $10 \%$ POM diet.

Table 5. Effects of poultry offal meal and enzyme supplementation on the performance of Japanese quails

\begin{tabular}{|c|c|c|c|c|c|c|c|}
\hline \multirow[b]{2}{*}{ Component } & \multicolumn{5}{|c|}{ Experiment 1} & \multirow[b]{2}{*}{ F value } & \multirow[b]{2}{*}{$\mathbf{P}>\mathbf{F}$} \\
\hline & $\mathbf{T 1}$ & $\mathbf{T} 2$ & T3 & T4 & T5 & & \\
\hline Weight gain (g/bird/day) & 2.63 & 2.66 & 2.75 & 2.62 & 2.68 & 0.09 & 0.99 \\
\hline Feed intake (g/bird/day) & 25.23 & 24.40 & 25.30 & 25.22 & 24.96 & 0.68 & 0.61 \\
\hline $\begin{array}{l}\text { FCR (kg feed/dozen } \\
\text { eggs)* }\end{array}$ & 0.62 & 0.72 & 1.65 & 0.69 & 0.79 & 1.86 & 0.12 \\
\hline FCR (kg feed/kg eggs)* & 5.77 & 6.36 & 4.46 & 6.24 & 4.96 & 1.89 & 0.12 \\
\hline Laying percentage $(\%)$ & 52.52 & 45.41 & 60.01 & 48.20 & 57.78 & 4.67 & 0.00 \\
\hline Mortality (\%) & 5.00 & 5.00 & 5.00 & 7.50 & 5.00 & $0.39 * *$ & 0.98 \\
\hline $\begin{array}{l}\text { Feed cost/ kg LWG*** } \\
\text { (SLRs) }\end{array}$ & 599.18 & 588.49 & 550.50 & 574.72 & 571.38 & 0.20 & 0.93 \\
\hline $\begin{array}{l}\text { Feed cost/ kg egg mass } \\
\text { (SLRs) }\end{array}$ & 307.80 & 362.80 & 262.70 & 348.70 & 271.20 & 1.29 & 0.32 \\
\hline
\end{tabular}

Experiment 2

\begin{tabular}{|c|c|c|c|c|c|c|c|}
\hline \multirow[b]{2}{*}{ Component } & & & & & & & \\
\hline & T1 & T3 & T5 & $\mathbf{T 3}+\mathrm{E}$ & T5+E & F value & $\mathbf{P}>\mathbf{F}$ \\
\hline Weight gain (g/bird/day) & 2.29 & 2.38 & 2.25 & 2.37 & 2.28 & 1.05 & 0.38 \\
\hline Feed intake (g/bird/day) & 23.34 & 22.50 & 22.51 & 22.83 & 22.75 & 0.91 & 0.46 \\
\hline $\begin{array}{l}\text { FCR (kg feed/ dozen } \\
\text { eggs)* }\end{array}$ & 0.52 & 0.79 & 0.48 & 0.63 & 0.86 & 0.73 & 0.57 \\
\hline FCR (kg feed/kg eggs)* & 6.30 & 5.70 & 5.19 & 5.01 & 12.12 & 2.21 & 0.08 \\
\hline Laying percentage (\%) & 36.62 & 34.41 & 40.05 & 41.96 & 26.06 & 5.98 & 0.00 \\
\hline Mortality (\%) & 10.00 & 5.00 & 5.00 & 10.00 & 5.00 & $1.84 * *$ & 0.77 \\
\hline $\begin{array}{l}\text { Feed cost / kg LWG*** } \\
\text { (SLRs) }\end{array}$ & 901.96 & 775.26 & 757.45 & 908.68 & 799.80 & 0.90 & 0.49 \\
\hline $\begin{array}{l}\text { Feed cost / kg egg mass } \\
\text { (SLRs) }\end{array}$ & 660.20 & 686.30 & 501.60 & 560.40 & 927.40 & 3.46 & 0.03 \\
\hline
\end{tabular}

\section{Feed conversion ratio}

The differences observed for FCR (Table 5) between the treatments were not statistically significant $(\mathrm{P}>0.05)$. The average values of FCR obtained in this study in terms of $\mathrm{kg}$ feed consumed to produce dozen eggs were comparatively higher than those reported by Berto $e t$ al., (2007) for Japaese quails $(0.39 \mathrm{~kg} / \mathrm{dz})$ fed with feeds containing different corn and lime stone particles. This may be mainly due to adoptation of mixed sex rearing system during the experimental period. In agreement with the results of the present study, non-significant effect of different inclusion levels of POM on feed conversion ratio has been reported for Japanese quails as well as for domestic fowl (Ali, 2003; Ertürk and Celik, 2004; Samli et al., 2006). Escalona and Pesti (1987) revealed that the feed efficiency was significantly $(\mathrm{P}<0.05)$ 
depressed when POM was incorporated into soybean meal-maize based diets for chicks at $10 \%$ level. However, absence of significant effect of increased levels of POM on FCR suggests that this protein source can be incoorporated at higher levels as suggested in previous studies. Poultry offal meal has been reported to be rich in methionine compared to SBM and it is also a good source of lysine and cystine (NRC, 1994). Perhaps, the complementary balance in amino acids in POM:SBM may be optimal at 10\% POM rate leading to increased egg production in Japanese quail layers resulting in lower FCR at $10 \%$ POM inclusion level.

\section{Laying percentage}

Laying percentage of Japanese quails was significantly affected $(\mathrm{P}<0.05)$ by dietary treatments (Table 5). The maximum average laying percentage was recorded from the birds fed with 5\% POM diet (Fig. 1) followed by 10\% POM diet. The laying percentages of these two dietary groups were significantly higher $(\mathrm{P}<0.05)$ than other groups. The treatment effect on laying percentage was not significant $(\mathrm{P}>0.05)$ when each week of laying was considered. Japanese quail hens fed 5 and 10\% POM had generally better rates of laying (14.6 and $10.0 \%$, respectively) than the laying rates of birds fed the control diet. Feeding 2.5 and $7.5 \%$ POM generally lowered the laying rate by 13.5 and $8.2 \%$, respectively as compared to the control group.

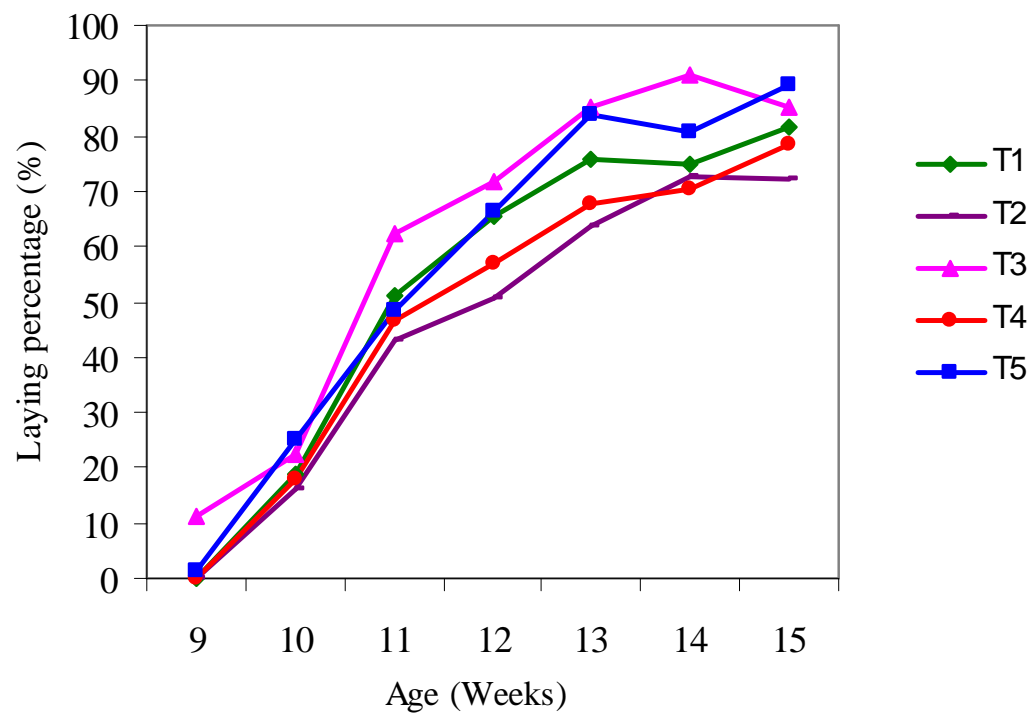

Fig. 1. Mean laying percentages (\%) of Japanese quails at different ages in

Experiment 1. $(\mathrm{T} 1=$ Control. $\mathrm{T} 2=2.5 \% \mathrm{POM}$ diet. $\mathrm{T} 3=5.0 \% \mathrm{POM}$ diet. $\mathrm{T} 4=$ $7.5 \%$ POM diet. $\mathrm{T} 5=10 \%$ POM diet)

As revealed by Ertürk and Celik (2004), the average egg production was not affected when the Japanese quails were fed with SBM-maize based diets containing 0, 20, 40, 60 and 80\% of POM as a replacement to SBM protein. However, the present study suggests POM can be incooperated into quail rations up to $10 \%$ without having any detremental effect on laying performance. 


\section{Mortality}

There was no treatment effect observed on the mortality of birds (Table 5). This is similar with the finding of Bolu and Adakeja (2008) for different mixing ratios of SBM and POM in diets of broiler chicks.

\section{Experiment 2}

\section{Weight gain}

Simililar to birds in experiment 1, the growth rate of birds in experiment 2 was also not affected by POM or by enzyme supplements (Table 5). This finding is in agreement with the findings of Elangovan et al., (2004) who described that the addition of feed enzymes to cornsoybean meal based diets was not beneficial in improving growth and nutrient utilization of Japanese quails. A similar finding to the present study was reported by Attia et al., (2008) for male and female Japanese quails fed with dietary enzymes.

\section{Feed intake}

The differences of feed intake between treatments (Table 5) were not statistically significant $(\mathrm{P}>0.05)$. However, the feed intakes of groups fed the POM were numerically improved by enzyme supplementation. A similar effect was found by Edwin et al., (2007) in Japanese quails fed with non-starch polysaccharide hydrolyzing enzymes (NSP) at different inclusion rates for 28 days.

\section{Feed conversion ratio}

The enzyme supplementation at 5\% POM numerically improved feed conversion efficiency compared to respective diet without enzymes(Table 5). This is in close agreement with the results of Elangovan et al., (2004) who reported that the enzyme supplementation did not improve feed conversion efficiency of Japanese quails, and the activities of commercial enzyme preparations were found to increas with the lowering of the dietary energy levels from 12.15 to 11.30 and $10.48 \mathrm{MJ} / \mathrm{kg}$. Similarly, it has been found that quail layers did not show any improvement by adding non-starch polysaccharide hydrolysing enzymes into their diets (Edwin et al., 2007).

In the present study, the dietary ME levels of all treatments were fixed at $12.1 \mathrm{MJ} / \mathrm{kg}$ and $12.3 \mathrm{MJ} / \mathrm{kg}$ in growing and laying phases, respectively to fullfill the standard nutritional requirements of Japanese quails. This might be the reason to produce similar results in performance trial and the absence of any advantage of enzyme supplementation during the experiment.

\section{Laying percentage}

Unlike growth rate and feed intake, the laying percentages of birds in different groups were significantly $(\mathrm{P}<0.05)$ affected by dietary treatments (Table 5$)$. The highest average laying percentage was observed from the birds fed with enzyme supplemented 5\% POM diet. Supplementation of enzymes improved the egg production by $21.9 \%$ at $5 \%$ POM. However, a significant $(\mathrm{P}<0.05)$ drop in egg production was noticed among the birds fed with enzyme supplemented diet containing 10\% POM compared to the diet formulated with same POM level without enzymes (Fig. 2). There was no significant difference $(\mathrm{P}>0.05)$ between the 
laying percentage of the birds fed with the control diet with other dietary treatments except for the diet containind 10\% POM with enzymes. The finding of this study partially agrees with the findings made by Elangovan et al., (2004), who concluded that the effect of enzyme supplementation on quail diets was found to be not beneficial to improve egg production. Attia et al., (2008) found that the Japanese quail hens fed an enzyme-supplemented $66 \%$ Nijella seed meal (NSM) diet laid significantly more eggs than the control group ( $0 \%$ NSM) and over the diet without enzyme supplementation. However, on the other hand, addition of enzymes to $100 \%$ NSM (0\% SBM) did not beneficially improve the egg production compared to the control and 100\% NSM diet. Enzymes attribute to higher levels of gut microflora in the small intestine in addition to their direct effect on nutrient digestion. Excess fermentation in intestines might be detremental to nutrient digestion and absorption (Wang et al., 2005). High inclusion rate of POM at $10 \%$ level might enhance fermentation when supplemented with dietary enzymes leading to lower digestibility and absorption of nutrients, required for egg production. This might be the reason for having poor laying rate at $10 \%$ POM when supplemented with enzymes.

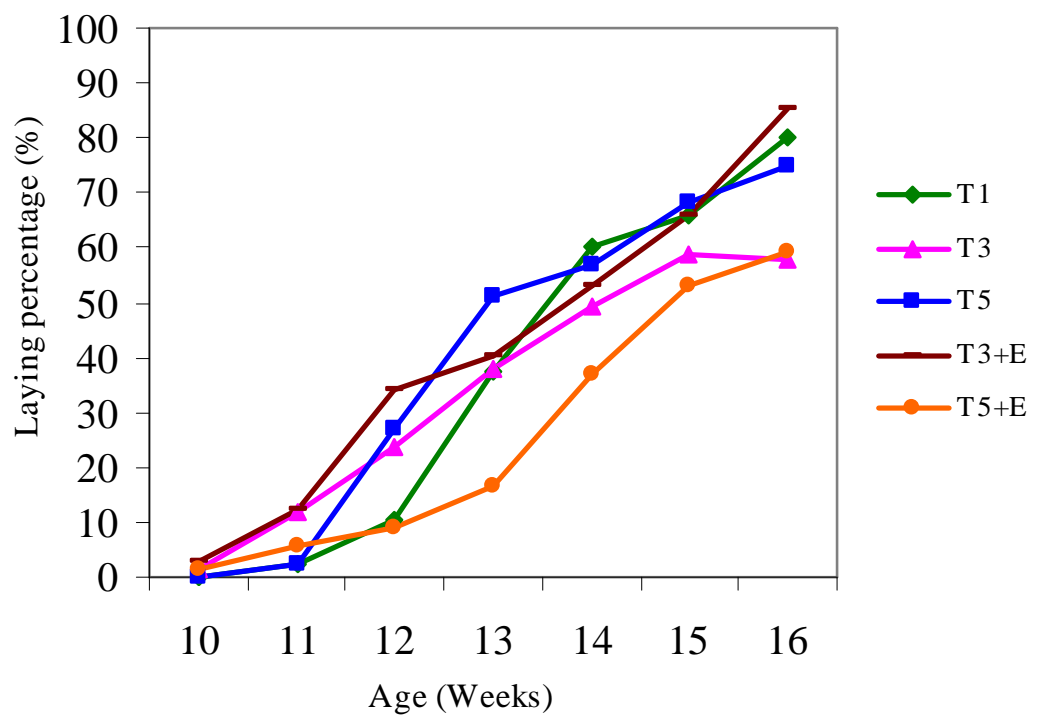

Fig. 2. Mean laying percentages (\%) of Japanese quails at different ages in Experiment 2.

$\mathrm{T} 1=$ Control. $\mathrm{T} 3=5.0 \%$ POM diet. $\mathrm{T} 5=10 \%$ POM diet T3+E $=$ Enzyme supplemented 5\% POM diet. T5+E= Enzyme supplemented 10\% POM diet

\section{Mortality}

Similar to expeimet 1 , the mortality of birds in the $2^{\text {nd }}$ experimet was also not affected by dietary treatments (Table 5).

\section{Cost beneifit analysis}

The cost of feed per $\mathrm{kg}$ live weight gain in Experiment 1 was inversely proportional to increasing level of POM. The lowest cost for $\mathrm{kg}$ live weight gain in Experiment 1 was realized from the diet with 5\% level POM. Replacement with POM at $10 \%$ inclusion level cut down the feed cost per kg live weight gain by $4.6 \%$ as compared to the control diet. 
The highest feed cost per kg live weight gain in Experiment 2 was obtained from the enzyme supplemented diet with 5\% POM, whereas the minimum average cost was recorded from the diet with 10\% POM (Table 5). Therefore, it is obvious that the cost dramatically reduces as the level of POM in diets declines together with enzyme supplementation. Since the performance parameters were not negatively affected by POM, the diet with $10 \%$ POM level could be suggested as the best balance in terms of feed cost per $\mathrm{kg}$ live weight gain considered in this study. Enzyme supplementation at 5\% and 10\% POM levels however, was not beneficial in cost reduction in terms of live weight gain compared to the diets with no enzymes. In experiment 1 , it has been revealed that $5 \%$ poultry offal meal diet was the best in terms of feed cost per kg eggs. In experiment 2, the best cost effective diet was the one with $10 \%$ POM where enzyme supplementation cut down the mean feed cost per kg eggs only by $26.9 \%$ at $5 \%$ poultry offal meal level.

\section{CONCLUSIONS}

This study revealed that the inclusion of poultry offal meal up to $10 \%$ had no detrimental effect on the performance of Japanese quails. The diet with $10 \%$ POM was identified as the most cost effective treatment and thereby selected as the best inclusion level. Enzyme supplementation improved the laying performance of birds at 5\% POM but not at 10\% POM. The enzyme supplementation was not effective in reducing the feed cost per kg live weight gain but, was effective in reducing the feed cost per kg egg mass at 5\% POM inclusion level.

\section{ACKNOWLEDGEMENT}

This investigation received 07/03). Authors wish to appreciate the assistance of the technical staff at Department of Livestock Production, Faculty of Agricultural Sciences, Sabaragamuwa University of Sri Lanka, Department of Animal Science, Faculty of Agriculture, University of Peradeniya, C.G.E. (Pvt) Limited, Colombo 15 and Veterinary Research Institute - Gannoruwa. The support of Dr. (Mrs.) Lakmali Ranathunghe, Faculty of Veterinary Medicine and Animal Science, University of Peradeniya and Dr (Mrs.) D.A.M. de Silva, Department of Agribusiness Management, Faculty of Agricultural Sciences, Sabaragamuwa University of Sri Lanka is highly appreciated.

\section{REFERENCES}

Ali, A.M. (2003). Effect of using poultry by-product meal on laying hen performance and egg quality. Egypt. J. Poult. Sci. 23(4): 825-841.

AOAC. (2002). Official Methods of Analysis, $17^{\text {th }}$ Edition. Association of Official Analytical Chemists, Gaithersburg, MD, USA.

Attia, Y.A., Tag El-Din, A.E.E., Zeweil, H.S., Hussein, A.S., Qota, E.M. and Arafat, M.A. (2008). The effect of supplementation of enzyme on laying and reproductive performance in Japanese quail hens fed Nigella seed meal. J. Poult. Sci. 45(2): 110-115.

Banerjee, G.C. (1998). Feeds and Principles of Animal Nutrition. Oxford and IBH Publishing. Co. Pvt. Ltd., 66, Janapath, New Delhi, India. 
Berto, D.A., Garcia, E.A., Móri, C., Faitarone, A.B.G., Pelícia, K. and Molino, A.B. (2007). Performance of Japanese quails fed feeds containing different corn and limestone particle sizes. Rev. Bras. Cienc. Avic. 9(3): 167-171.

Bolu, S.A. and Adakeja, A. (2008). Effects of poultry offal meal and soybean meal mixtures on the performance and carcass quality of broiler chicks. Afr. J. Food Agric. Nut. Develop. 8(1): 28-37.

Daghir, N.J. (1975). Studies on poultry by-product meals in broiler and layer rations. World's Poult. Sci. J. 31(3): 200-211.

Dudley Cash, W.A. (2001). Soybean meal source, added enzyme affect nutritional value for chicks. Feedstuffs 73: 41.

Edwin, S.C., Viswanathan, K., Mohan, B. and Purushothaman, M.R (2007). Egg production performance of Japanese quail fed with NSP hydrolyzing enzymes. Ind. Vet. J. 84(8): 871872.

El-Sheikh, M.A.M., Soliman, A.F., Abdella, M.M., El- Sayaad G.A.E. and Hussein, H.H. (1996). The nutritive value of hydrolyzed feather and poultry offal meals in broiler rations. Ann. Agr. Sci. 34(1): 157-170.

Elangovan, A.V., Mandal, A.B., Tyagi, P.K., Toppo, S. and Johri, T.S. (2004). Effects of enzymes in diets with varying energy levels on growth and egg production performance of Japanese quail. J. Sci. Food Agric. 84(15): 2028-2034.

Ertürk, M.M. and Celik, S. (2004). Substitution of poultry by-product meal in diets of breeder Japanese quail (Coturnix coturnix japonica): 1- Effects on performance parameters. J. Fac. Agric. Akdeniz Uni. 17(1): 59-66.

Escalona, P. and Pesti, G.M. (1987). Research note: nutritive value of poultry by- product meal.3. Incorporation in to practical diets. Poult. Sci. 66(6): 1067-1070.

Fritts, C.A., Kersey, J.H. and Waldroup, P.H. (2002). Utilization of spent hen meal in diets for laying hens. Inter. J. Poultry Sci. 1(4): 82-84.

Gopalkrishnan, C.A., (2003). Quail may alleviate hunger in developing countries. Poult. Int. 42(03): 42-43.

Harris, L.E. (1966). Biological energy interrelationships and glossary of energy terms. Publi. 1411, National Academy of Science. National Research Council, Washington, D.C.

Hassanabadi, A., Amanloo, H. and Zamanian, M. 2008. Effects of substitution of soybean meal with poultry by- product meal on broiler chick performance. J. Anim. Vet. Adv. 7(3): 303-307.

Janssen, W.M.M.A. (1989). European Table of Energy Values for Poultry Feedstuffs, Spelderholt Center for Poultry Research and Information Service, Beekbergen, Netherlands. 
Leeson, S. and Summers, J.D. (2005). Commercial Poultry Nutrition. University Books, Guelph, Ontario, Canada.

Minitab Inc. (2003). MINITAB Statistical Software, Release 14 for Windows, State College, Pennsylvania.

Najafabadi, H.J., Moghaddam, H. N., Pourreza, J., Shahroudi, F.E. and Golian, A. (2007). Determination of chemical composition, mineral contents and protein quality of poultry byproduct meal. Int. J. Poult. Sci. 6(12): 875-882.

NRC, (1994). National Research Council, Nutrient Requirements of Poultry. National Academy Press. Washington DC.

Pesti, G.M. (1987). The nutritional value of poultry by-product meal. Recent Advances in Animal Nutrition in Australia. The University of New England, Armidale. 176-181.

Samarasinghe, K., Priyalal, N. C. and Gunasekera, J.M.D.M. (2002). Supplemental lipase and mannanoligosachcharides to improve the nutritive value of poultry by-product meal and its use as a substitute for fish meal in broiler diets. Proc. $58^{\text {th }}$ Annual Sessions of Sri Lanka Association for the Advancement of Science. $02-07$ Dec. 2002. 50.

Samarasinghe, K., (2007). Feeds and Feed Formulation for Poultry in Sri Lanka, Department of Animal Science, Faculty of Agriculture, University of Peradeniya, Sri Lanka.

Samli, H.E., Senkoylu, N., Ozduven, M.L., Akyurek, H. and Agma, A. (2006). Effects of poultry by-product meal on laying performance, egg quality and storage stability. Pak. J. Nut. 5(1): 6-9.

SAS Institute, (2002). SAS/ STAT ${ }^{\circledR}$ User's Guide. Version 9 Edition. SAS Institute Inc. Cary, NC.

Wang, Z.R., Qiao, S.Y., Lu, W.Q. and Li, D.F. (2005). Effects of enzyme supplementation on performance, nutrient digestibility, gastrointestinal morphology and volatile fatty acid profiles in the hind gut of broilers fed wheat-based diets. Poult. Sci. 84(6): 875-881. 